\title{
Black Molds and Melanized Yeasts Pathogenic to Humans
}

\author{
Anuradha Chowdhary ${ }^{1}$, John Perfect ${ }^{2}$, and G. Sybren de $\operatorname{Hoog}^{3}$ \\ ${ }^{1}$ Department of Medical Mycology, Vallabhbhai Patel Chest Institute, University of Delhi, Delhi 110 007, India \\ ${ }^{2}$ Division of Infectious Diseases, Department of Medicine, Duke University Medical Center Durham, North \\ Carolina 27710 \\ ${ }^{3}$ CBS-KNAW Fungal Biodiversity Centre, 3508 AD Utrecht, The Netherlands \\ Correspondence: de.hoog@cbs.knaw.nl
}

\begin{abstract}
A review is given of melanized fungi involved in human infection, including species forming budding cells and strictly filamentous representatives. Classically, they are known as "phaeoid" or "dematiaceous" fungi, and, today, agents are recognized to belong to seven orders of fungi, of which the Chaetothyriales and Pleosporales are the most important. Infections range from cutaneous or pulmonary colonization to systemic or disseminated invasion. Subcutaneous involvement, either primary or after dissemination, may lead to host tissue proliferation of dermis or epidermis. Particularly in the Chaetothyriales, subcutaneous and systemic infections may occur in otherwise apparently healthy individuals. Infections are mostly chronic and require extended antifungal therapy and/or surgery.
\end{abstract}

B ecause melanin is a factor-enhancing virulence, black fungi are overrepresented as etiologic agents of opportunistic infection. Traditionally, they have been collectively indicated under umbrella terms, such as "dematiaceous" or "phaeoid" fungi, referring to the presence of brown hyphae or yeast cells. Today, the leading principle of fungal classification is molecular phylogeny. The melanized fungi appear to belong to distantly related orders of Ascomycota, and the descriptive terminology above has therefore become obsolete. Clinically, they are involved in infections ranging from mild, hardly noticeable cutaneous infections (Saunte et al. 2011) to fatal brain diseases in otherwise healthy individuals (Al-Tawfiq and Boukhamseen 2011). Tissue forms range from melanized hyphae, yeast cells, or muriform cell clumps. The term "phaeohyphomycosis" (or phaeomycosis, a better term not excluding yeast cells) is therefore useful by negation, that is, a mycosis not caused by a hyaline fungus, but otherwise its information content is minimal. The fungi listed in this article are in alphabetical order according to genus with their phylogenetic affiliation in parentheses.

The characteristic common to all species treated in this article is the presence of melanin in cell walls, which is responsible for the dark color of hyphae, yeast cells, muriform cell clumps, and conidia, and is believed to be a major virulence factor-enhancing opportunism. The function of melanin in their natural habitat mostly is protection against solar irradiation

Editors: Arturo Casadevall, Aaron P. Mitchell, Judith Berman, Kyung J. Kwon-Chung, John R. Perfect, and Joseph Heitman Additional Perspectives on Human Fungal Pathogens available at www.perspectivesinmedicine.org

Copyright (C) 2015 Cold Spring Harbor Laboratory Press; all rights reserved; doi: 10.1101 /cshperspect.a019570 Cite this article as Cold Spring Harb Perspect Med 2015;5:a019570 
A. Chowdhary et al.

because of growth on exposed surfaces, such as natural rock, or against factors prevalent under conditions of stress. Another main type of natural ecology is in decomposing plant material; if the orders concerned preponderantly contain plant pathogens, then the human opportunists are found among the few saprobes on plant debris in that group. Clinical pathology mostly emerges from traumatic introduction in or below the skin resulting in a suppurative foreign body response. Inhalation mycoses are exceptional and mostly confined to pulmonary colonization in patients with cystic fibrosis. Deepseated infections can be, depending on the species, disseminated or cerebral; their portal of entry is poorly understood. A special category is chromoblastomycosis, a disease exclusively caused by members of the Herpotrichiellaceae (black yeasts and relatives in the order Chaetothyriales), and is clinically exceptional by a host response with hyperproliferation rather than necrosis; the tissue form consists of muriform (sclerotic) cells. Although diseases by melanized fungi are rare, they are significant because of their occurrence in otherwise healthy individuals, and no notable increase in their frequency is noticed with the emergence of immunocompromised hospital populations. Decreased immunity, as well as diabetes, nevertheless, are risk factors for infection. Recently, some of the highly recalcitrant, disseminated infections appeared to be associated with mutations in the host's dectin signaling pathway (Wang et al. 2014).

\section{CLINICAL SPECTRUM OF DISEASES CAUSED BY BLACK FUNGI}

Colonization. Asymptomatic growth of melanized fungi is known on human skin as well as in the lungs, particularly when patients suffer from cystic fibrosis. The systemic colonizers have an invasive potential when the host immune barriers are broken, whereas colonizers of skin and nails cause cutaneous infections at most.

Superficial. Growth on human skin has classically been reported from Hortaea werneckii, which mainly colonizes the epidermis but also from members of Cyphellophora and
Phialophora, which are known to be involved in mild skin infections and onychomycoses (Fig. 2).

Cutaneous. Cutaneous infections are uncommon. Mostly cystic or papular lesions on exposed body areas are of concern in patients under prolonged corticosteroid therapy. Alternaria (Fig. 1B, left) and Exophiala species are the most common etiological agents.

Subcutaneous. Subcutaneous infections can be necrotic phaeomycoses with hyphae or yeastlike cells in tissue, or are eumycetomata, lesions being granulomatous abscesses with draining sinuses from which granules of dense fungal material may be recovered. Osteomyelitis may occur. Etiologic agents mainly are found in Madurella, Phaeoacremonium, in coelomycetous representatives of Pleosporales, and occasionally in Exophiala.

Chromoblastomycosis. This is a chronic subcutaneous infection caused by members of Herpotrichiellaceae (black yeasts and relatives) and characterized by the presence of muriform cells (sclerotic bodies) in tissue sections or wet preparations of pus or scrapings. Cladophialophora carrionii, Fonsecaea monophora, Fonsecaea pedrosoi, Rhinocladiella aquaspersa, and occasionally Phialophora verrucosa are the fungal species involved. C. carrionii is endemic to arid climate zones, whereas Fonsecaea species are preponderantly found under tropical conditions.

Systemic. Cerebral abscesses are rare but fatal if untreated and are mainly reported from immunocompetent individuals (Carter and Boudreaux 2004; Delfino et al. 2006; Chang et al. 2009; Al-Tawfiq and Boukhamseen 2011). The most common neurotropic fungi, Rhinocladiella mackenziei, Cladophialophora bantiana, Exophiala dermatitidis, and F. monophora, are members of Herpotrichiellaceae, but also Exserohilum, Bipolaris (Pleosporaceae), and Verruconis (Sympoventuriaceae) can be involved. Some species are endemic to the Middle East or East Asia or show an increased prevalence in India (Delfino et al. 2006; Garg et al. 2007; Li and de Hoog 2009; Al-Tawfiq and Boukhamseen 2011; Jabeen et al. 2011; Pedersen et al. 2011). Central nervous system (CNS) infections by Herpotrichiellaceae are hypothesized to be acquired via inhalation and then quickly disseminated to the 

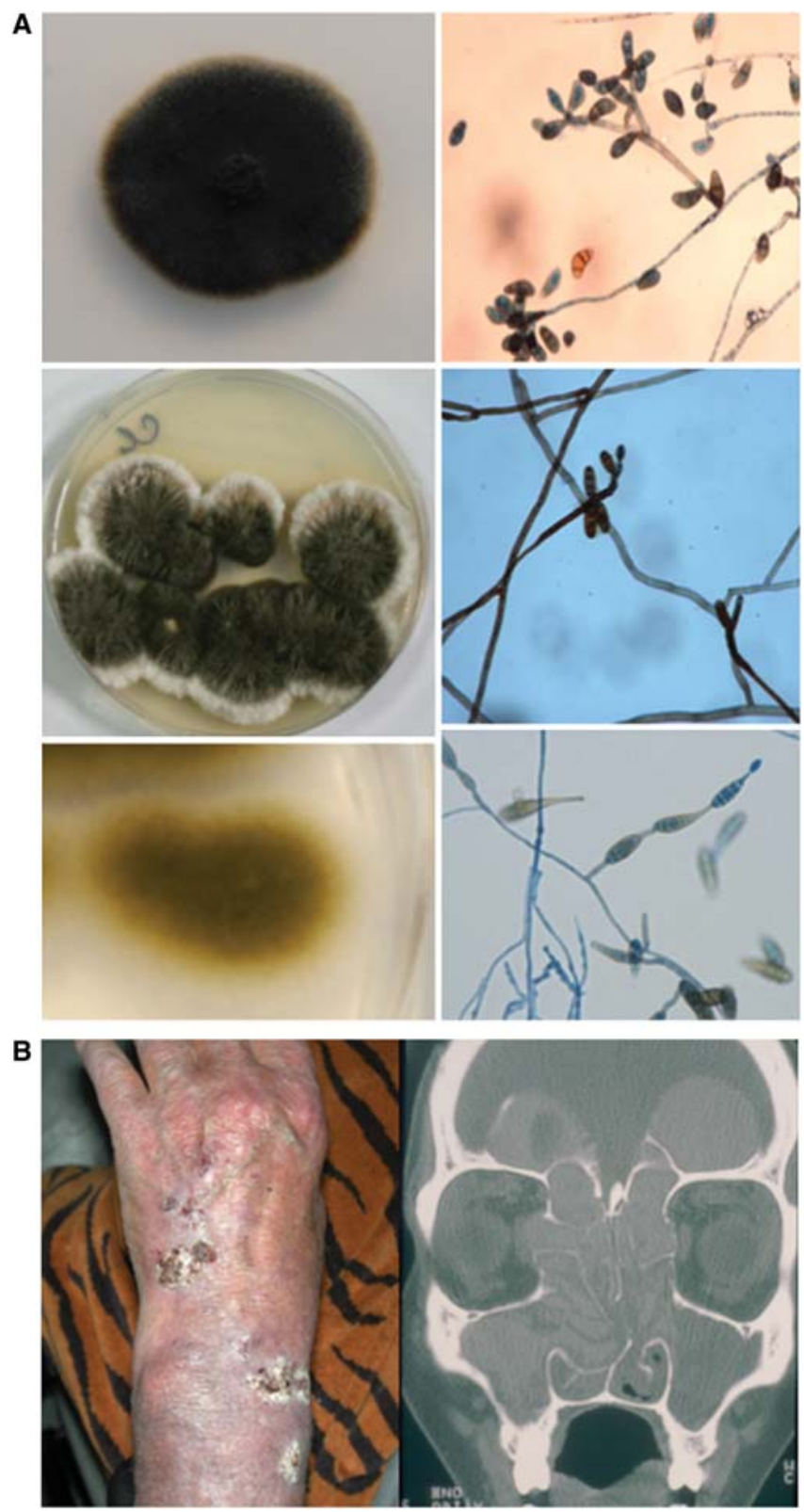

Figure 1. Pleosporalean agents. (A) Top row, Curvularia lunata; middle row, Bipolaris hawaiiensis; bottom row, Alternaria alternata. (B) Left, Alternaria cutaneous infection; right, Bipolaris chronic sinusitis.

CNS via the hematogenous route; but because of a long asymptomatic period of incubation, the actual route of infection may be difficult to establish. Another better-known development of CNS infection, mostly seen in Pleosporaceae, is secondary to chronic fungal sinusitis (Fig. 1B, right).
Disseminated. This type of infection is almost exclusively caused by members of Herpotrichiellaceae. The infections are very chronic, with a long incubation period, and highly refractory to therapy. Hematogenous spread of the fungus to one or more distant sites may 
A. Chowdhary et al.
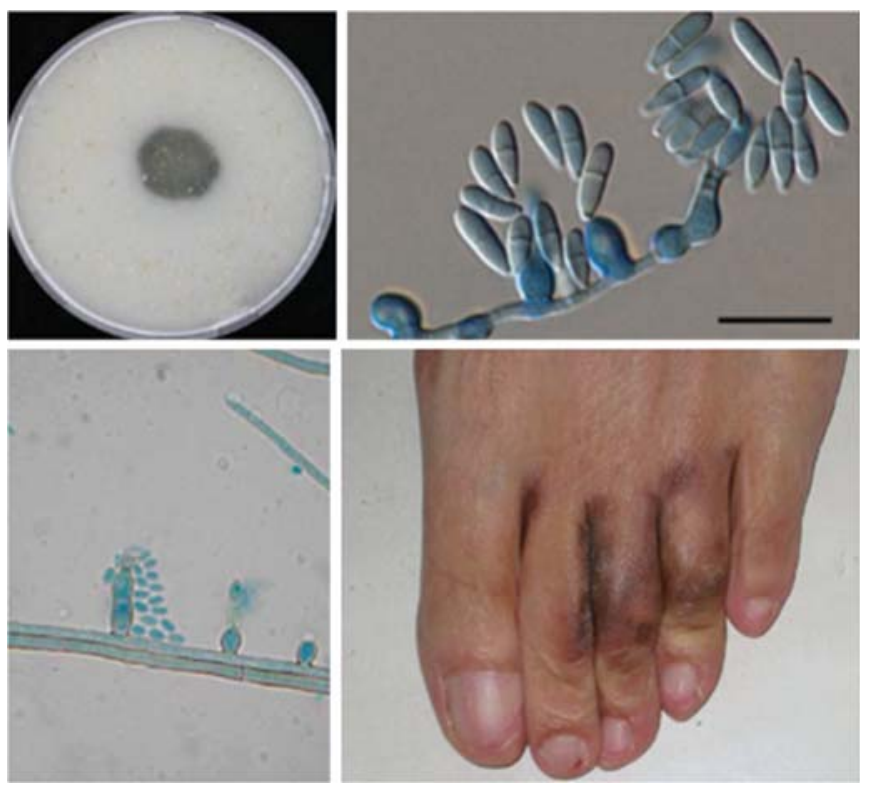

Figure 2. Chaetothyrialean agents of superficial mycoses. Upper row: Cyphellophora pluriseptata; lower row: left, Phialophora europaea; right, superficial infection. Scale bar, $10 \mu \mathrm{m}$.

result in visceral infections of the heart and heart valves, brain, joints, bone, kidney, liver, lymphatics, pancreas, and other organs. Secondary cutaneous lesions emerging on all parts of the body are characterized by tissue proliferation of the host, resembling chromoblastomycosis. In most patients, no predisposing factors are recognized, although some rare mutations in the dectin signaling cascade have been noted (Wang et al. 2014). The main black fungi involved are Exophiala and Veronaea (Bonifaz et al. 2013).

A summary of prevalent clinical syndromes is given in Table 1. Descriptions of relevant genera listed alphabetically below are attributed according to their phylogenetic position in the fungal kingdom.

\section{Acrophialophora (Sordariales: Coniochaetaceae)}

The small genus Acrophialophora comprises of some soil-borne fungi occasionally involved in human infection (de Hoog et al. 2000). Reports of brain abscess and cases involving lung and cornea have been reported (Al-Mohsen et al.
2000; Guarro et al. 2007; Li et al. 2013). The relevant species Acrophialophora fusispora forms white to buff colonies with darker concentric circles on Sabouraud's glucose agar. Conidiogenous cells are flask-shaped phialides with long and narrow necks, occurring alongside of thin-walled, hyaline to pale-brown hyphae, or on unbranched, brown, thick-walled, and echinulate conidiophores (Al-Mohsen et al. 2000). Conidia are limoniform, pale brown, echinulate with ornamentation in spiral bands, and adhere in long chains (de Hoog et al. 2000). Because of the scarcity of data, treatment of the infections attributed to this fungus is not well established.

\section{Alternaria (Pleosporales: Pleosporaceae)}

Alternaria is a large genus of mainly plant pathogens and some saprobes on plant debris, and found in air or in soil (de Hoog et al. 2000; Tournas 2005; De Lucca 2007). Clinical manifestations of the saprobic Alternaria species usually are cutaneous or subcutaneous lesions after trauma (Halaby et al. 2001; Lo Cascio et al. 2004) in patients under prolonged corticosteroid treatment. Other clinical entities, such as 
Black Molds and Yeasts Pathogenic to Humans

Table 1. Overview of spectrum of prevalent diseases caused by black fungi

\begin{tabular}{|c|c|c|}
\hline Order & Etiologic genus & Prevalent clinical manifestation $^{a}$ \\
\hline Capnodiales & Hortaea & Cutaneous colonization \\
\hline \multirow[t]{8}{*}{ Chaetothyriales } & Cladophialophora & Brain abscess, (sub)cutaneous infection, chromoblastomycosis \\
\hline & Cyphellophora & Cutaneous colonization, onychomycosis \\
\hline & Exophiala & $\begin{array}{l}\text { Brain abscess, chromoblastomycosis, (sub)cutaneous infection, } \\
\text { pneumonia, eumycetoma }\end{array}$ \\
\hline & Fonsecaea & Chromoblastomycosis, brain abscess \\
\hline & Knufia & Skin colonization \\
\hline & Phialophora & $\begin{array}{l}\text { Subcutaneous infection, disseminated, chromoblastomycosis, } \\
\text { cutaneous colonization }\end{array}$ \\
\hline & Rhinocladiella & Brain abscess, chromoblastomycosis \\
\hline & Veronaea & (Sub)cutaneous infection, disseminated \\
\hline Diaporthales & Phaeoacremonium & $\begin{array}{l}\text { Subcutaneous infection, eumycetoma, fungemia, osteomyelitis, } \\
\text { arthritis, endocarditis }\end{array}$ \\
\hline \multirow[t]{2}{*}{ Dothideales } & Aureobasidium & (Sub)cutaneous infection, fungemia, meningitis, peritonitis \\
\hline & Neoscytalidium & Onychomycosis, cutaneous infection, fungemia \\
\hline \multirow[t]{11}{*}{ Pleosporales } & Alternaria & $\begin{array}{l}\text { (Sub)cutaneous infection, sinusitis, keratitis, onychomycosis, } \\
\text { ABPM, disseminated }\end{array}$ \\
\hline & Biatriospora & Eumycetoma \\
\hline & Bipolaris & $\begin{array}{l}\text { (Sub)cutaneous infection, sinusitis, keratitis, ABPM, } \\
\text { pneumonia, disseminated }\end{array}$ \\
\hline & Curvularia & $\begin{array}{l}\text { (Sub)cutaneous infection, sinusitis, keratitis, ABPM, } \\
\text { eumycetoma, peritonitis, onychomycosis, brain abscess, } \\
\text { disseminated }\end{array}$ \\
\hline & Exserohilum & $\begin{array}{l}\text { Brain abscess, chromoblastomycosis, (sub)cutaneous infection, } \\
\text { pneumonia, eumycetoma }\end{array}$ \\
\hline & Falciformispora & Eumycetoma \\
\hline & Medicopsis & Eumycetoma \\
\hline & Phoma & (Sub)cutaneous infection, keratitis \\
\hline & Pseudochaetosphaeronema & Eumycetoma \\
\hline & Pyrenochaeta & Keratitis, onychomycosis, (sub)cutaneous infection, eumycetoma \\
\hline & Trematosphaeria & Subcutaneous infections \\
\hline \multirow[t]{3}{*}{ Sordiales } & Acrophialophora & Brain abscess, keratitis \\
\hline & Chaetomium & Brain abscess, (sub)cutaneous infection, pneumonia, eumycetoma \\
\hline & Madurella & Eumycetoma \\
\hline \multirow[t]{2}{*}{ Venturiales } & Ochronis & Cutaneous infection \\
\hline & Verruconis & Pneumonia, brain abscess, disseminated \\
\hline
\end{tabular}

${ }^{\mathrm{a}}$ Infections possible in otherwise healthy-appearing patients. Infections exclusively occurring in immunocompromised patients are shown in bold.

cerebral infections, sinusitis, keratitis, and allergic bronchopulmonary mycosis, are very rare (Hipolito et al. 2009; Chowdhary et al. 2012, 2014a). The most common etiologic agents are Alternaria alternata and Alternaria infectoria and, occasionally, Alternaria chlamydospora. A. infectoria may be difficult to recognize because of its often poor sporulation on routine media and loss of melanin in vitro and in tissue. The taxonomy and identification of other reported species, such as Alternaria dianthicola, Alternaria longipes, and Alternaria tenissima, has been insufficiently clarified. Morphologically, colonies generally are expanding, hairy, with gray to olivaceous black colors. Conidiophores are mostly erect, brown, and multicelled, producing conidia in sympodial order, leaving flat, dark-brown scars. The conidia are usually brown, smooth walled, or verruculose with a round base and beaked tip, with muriform septation, and are produced in 
A. Chowdhary et al.

chains. Morphological characteristics distinguishing $A$. alternata from $A$. infectoria are the conidia, which often become nearly tubular and occur in strongly branched chains in the latter species. Conidia resemble multicelled chlamydospores in A. chlamydospora. Sequencing of the rDNA internal transcribed spacer (ITS) region is sufficient for routine identification of $A$. alternata and $A$. infectoria (Hipolito et al. 2009; Cunha et al. 2012).

\section{Aureobasidium (Dothideales: Dothiodeaceae)}

Aureobasidium pullulans is a black yeast-like fungus that is ubiquitous on poor-nutrient surfaces, such as on plant leaves, glass, and damp bathroom walls, and is commonly found as a contaminant in clinical laboratories. Recently, intraspecific molecular diversity has been found, which has led to the description of varieties and sibling species (Zalar et al. 1999). Opportunistic infections are mostly caused by A. pullulans but also other taxa have been reported, such as $A u$ reobasidium proteae (de Hoog et al. 2000; Kutleša et al. 2012). Most infections occur by traumatic inoculation, such as keratitis and cutaneous lesions; disseminated mycoses are very rare and occur only in severely immunocompromised patients (Kaczmarski et al. 1986; Salkin et al. 1986; Arranz et al. 2006; Panda et al. 2006; Mise et al. 2008; Pikazis et al. 2009; Chawla et al. 2010; Joshi et al. 2010; Mershon-Shier et al. 2011). A. pullulans has an affinity for synthetic materials and surgically implanted devices, as evidenced by the relatively frequent isolation of the organism from peritoneal dialysis catheters and central venous lines (Clark et al. 1995; Caporale et al. 1996; Hawkes et al. 2005; Mise et al. 2008). The in vitro activity of antifungals against $A$. pullulans revealed resistance to fluconazole and high minimum inhibitory concentrations of voriconazole, isavuconazole, caspofungin, and micafungin. However, the isolates exhibit susceptibility to amphotericin B, posaconazole, and itraconazole (Najafzadeh et al. 2014). Colonies grow rapidly and are smooth, cream to pink, covered with slimy exudates, and become variably brown or black in a later stage.
On microscopic examination, large, hyaline hyphae are seen, which variably convert into thickwalled, dark-blackish-brown chlamydosporelike cells. Conidia are produced synchronously in groups alongside undifferentiated hyphae. Species distinction is by ITS sequencing.

\section{Biatriospora (Pleosporales: Trematosphaeriaceae)}

This single species B. mackinonii was formerly classified in Pyrenochaeta or Nigrograna. The species is an occasional agent of human mycetoma. The natural habitat of this fungus is unknown. Colonies are gray, velvety, becoming dark gray to black with age. Pycnidia are solitary, globose to pyriform, with papillate ostioles. Conidiogenous cells are hyaline, phialidic, and discrete. Conidia are subhyaline, brown in mass, one celled, and ellipsoidal (Ahmed et al. 2014).

\section{Bipolaris (Pleosporales: Pleosporaceae)}

Most species belonging to the genus Bipolaris are host-specific pathogens on grasses, whereas some saprobic species in soil with dead and decaying plant material can be found as human opportunists (Revankar et al. 2010). The prevalent clinically significant saprobes are Bipolaris australiensis, Bipolaris hawaiiensis, and Bipolaris spicifera (Sivanesan 1987; da Cunha et al. 2012a). They are particularly associated with chronic pansinusitis (Toul et al. 2006). Other cases include endophthalmitis and orbital cellulitis (Newell et al. 2006; Sheyman et al. 2013), necrotizing pneumonia and allergic bronchopulmonary mycosis (Saenz et al. 2001; Chowdhary et al. 2011, 2014b), peritonitis (Bava et al. 2003), endarteritis (Ogden et al. 1992), and encephalitis (Morton et al. 1986; Pauzner et al. 1997). Colonies are black, hairy, and expanding. Conidiophores are brown, erect, multicelled, producing ellipsoidal, straight, or curved conidia with darkbrown, flat conidial scars. Molecular identification can be done using ITS sequencing. A specific polymerase chain reaction (PCR) has been developed for the direct detection of Bipolaris species (Shin et al. 2003; El-Morsy et al. 2010). 


\section{Chaetomium (Sordariales: Chaetomiaceae)}

This genus comprises more than 180 species from straw, plant debris, and animal dung (Guarro 1998; de Hoog and Vitale 2007). The significance of the genus has been underestimated because clinical strains are mostly sterile in culture, and could not be recognized by morphology (de Hoog et al. 2013). Clinically significant species include Chaetomium globosum, followed by Chaetomium strumarium, Chaetomium atrobrunneum, Chaetomium funicola, and Chaetomium perlucidum (Abbott et al. 1995; Guarro et al. 1995; Yeghen et al. 1996; Guppy et al. 1998; Lesire et al. 1999; Thomas et al. 1999). Chaetomium species have mainly been reported from onychomycosis and sinusitis (Aru et al. 1997; Stiller et al. 1992). Brain infection is sometimes seen in individuals during illicit intravenous drug use (Abbott et al. 1995). A chromoblastomycosis-like infection by $C$. funicola was reported by Piepenbring et al. (2007); this is an exceptional case of this disease caused by a fungus in the Herpotrichiellaceae. The distinctive feature of Chaetomium species is the presence of pronounced hairs, or setae, on the spherical to pyriform fruit bodies. The hairs may be dichotomously branched or unbranched and are often undulate or spirally coiled. Asci are usually eight-spored and deliquescent so that brown, one-celled ascospores are easily liberated in large masses. Opportunistic species are thermotolerant; C. globosum grows at $35^{\circ} \mathrm{C}$ but not at $40^{\circ} \mathrm{C}$, whereas the neurotropic species C. atrobrunneum and C. perlucidum grow at $40^{\circ} \mathrm{C}$ (von Arx et al. 1986; Barron et al. 2003).

\section{Cladophialophora (Chaetothyriales: Herpotrichiellaceae)}

Cladophialophora is morphologically characterized by one-celled, ellipsoidal to fusiform, and dry conidia, arising in long, branched, or unbranched chains. Cladophialophora species are involved in a wide diversity of infections, ranging from mild cutaneous to fatal encephalitis (Borelli 1980; Ho et al. 1999; de Hoog et al. 2000). An important species is the neurotropic fungus, C. bantiana, of which more than 100 case reports in mostly healthy individuals have been published. Cladophialophora modesta was responsible for a case after head trauma (McGinnis et al. 1999). C. carrionii is the prevalent agent of chromoblastomycosis in dry climates and desert zones (Mendoza et al. 1993; Jayakeerthi et al. 2004; Ameen 2009). Cladophialophora devriesii and Cladophialophora arxii are rare agents of disseminated diseases, whereas Cladophialophora boppii, Cladophialophora emmonsii, and Cladophialophora saturnica are causes of mild cutaneous infections (Fig. 3) (Badali et al. 2008).

\section{Curvularia (Pleosporales: Pleosporaceae)}

This genus consists of $\sim 100$ species, most of which are either saprobes in soil or on plant debris, or are plant pathogens mainly infecting grasses (Sivanesan 1987). Human infections have been reported in Curvularia aeria, Curvularia geniculata, and Curvularia lunata; isolated cases occurred in Curvularia brachyspora, Curvularia clavata, Curvularia inaequalis, Curvularia pallescens, and Curvularia verruculosa. Curvularia species may cause allergic sinusitis, which can disseminate to the brain of immunocompetent patients (Ebright et al. 1999). Other manifestations include subcutaneous infections following traumatic implantation, such as keratitis. Colonies of Curvularia are black in color, expanding, and hairy (Tanabe et al. 2010; Moody et al. 2012). Conidiophores are brown and erect, producing ellipsoidal, brown, usually curved conidia with three or four transverse septa. Species can be differentiated on the basis of ITS and glyceraldehyde-3-phosphate dehydrogenase gene sequences (de Hoog and Vitale 2007).

\section{Cyphellophora (Chaetothyriales: Herpotrichiellaceae-Cyphellophoraceae)}

The natural habitat of members of the small genus Cyphellophora has not been established with certainty. They are mainly known from human skin and nails, where they can be symptomatic or subclinical, but detailed case reports are as yet lacking (Feng et al. 2014). The species 
A. Chowdhary et al.
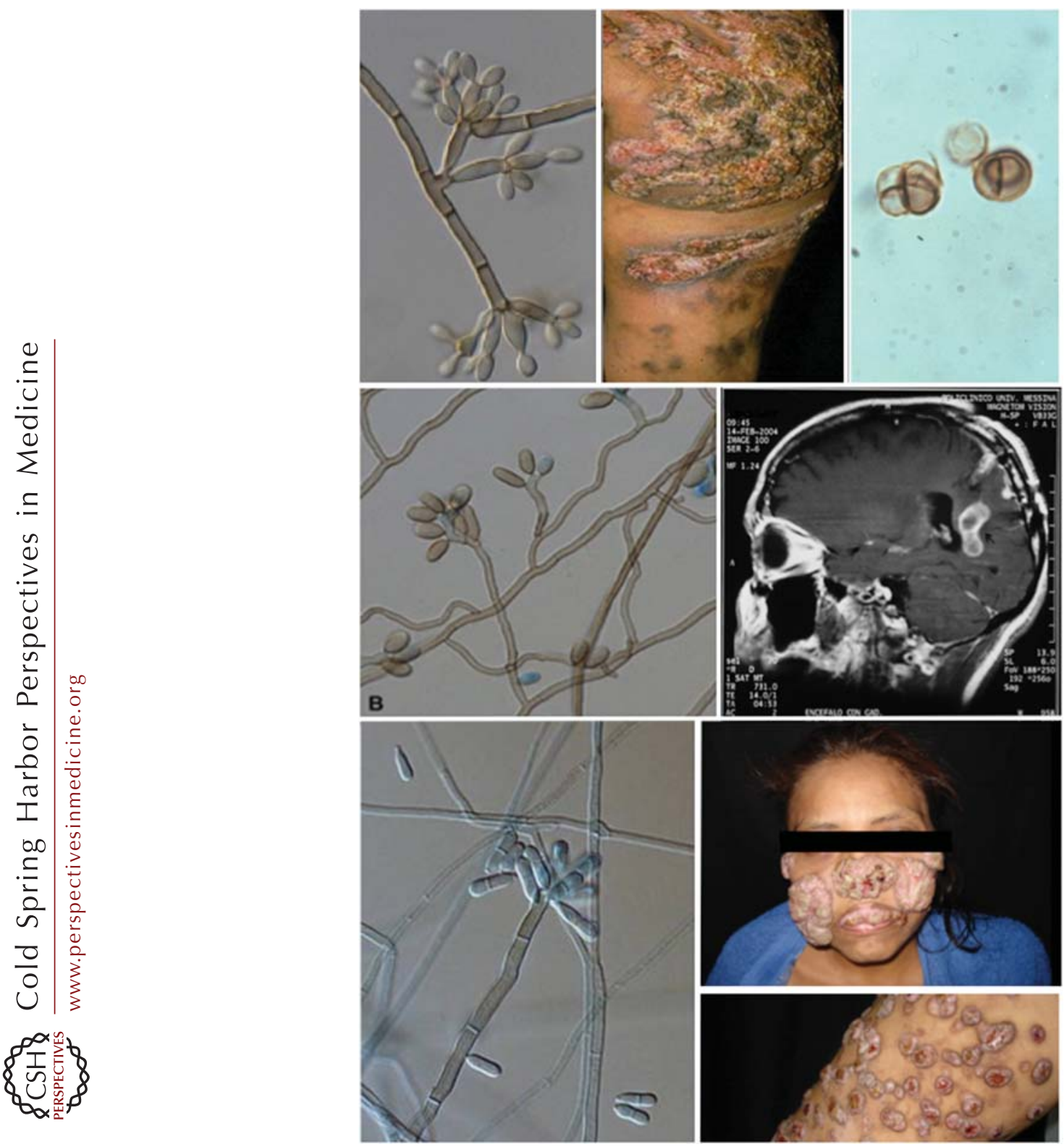

Figure 3. Chaetothyrialean agents of deep infections. Upper row: Fonsecaea pedrosoi causing chromoblastonycosis with muriform cells; middle row: Ramichloridium mackenziei, agent of cerebral phaemycosis (case shown caused by Cladaphialophora bantiana); bottom row: disseminated infection caused by Veronaea botryosa.

grow very slowly with olivaceous black colonies and produce thin-walled, sickle-shaped conidia with one or several transverse septa. Conidia are produced in packages from phialide openings on spherical conidiogenous cells or directly from hyphae.

\section{Exophiala (Chaetothyriales: \\ Herpotrichiellaceae)}

Exophiala is the major genus of black yeasts, characterized by annelidic conidiogenesis and the presence of torulose hyphae, that is, hyphae 
composed of chains of more or less spherical cells. They are typically associated with nutrient-poor or toxic environments, such as creosoted wood (Döğen et al. 2013), toxic mines (Seyedmousavi et al. 2011), or steam baths (Sudhadham et al. 2008). The common clinically relevant species include E. dermatitidis, Exophiala xenobiotica, Exophiala spinifera, and Exophiala oligosperma. Less common are Exophiala lecanii-corni, Exophiala asiatica, Exophiala phaeomuriformis, Exophiala jeanselmei, Exophiala bergeri, and Exophiala mesophila (de Hoog et al. 2003; Zeng et al. 2007; Badali et al. 2010). E. dermatitidis causes disseminated infection eventually with neurotropism, whereas E. spinifera is osteotropic (Horre and de Hoog 1999; Kantarcioglu and de Hoog 2004; Harris et al. 2009; Badali et al. 2010). Exophiala colonies are restricted, olivaceous black, and often initially slimy at the center and then becoming velvety toward the margin. Conidiogenous cells are intercalary or lateral, cylindrical, flask shaped or acicular, with relatively narrow, short, or very short annellated zones. Conidia are generally present in clumps. Molecular identification for most species is by ITS sequencing because they generally show very limited morphological differentiation (Zeng et al. 2007; Najafzadeh et al. 2013).

\section{Exserohilum (Pleosporales: Pleosporaceae)}

The genus Exserohilum comprises 35 saprobic species mainly feeding on plant debris. In the clinical literature, three clinically significant species have been reported (Exserohilum rostratum, Exserohilum longirostratum, and Exserohilum mcginnisii), but molecular studies demonstrated that they belong to a single species, E. rostratum (da Cunha et al. 2012b). Exserohilum species are mainly involved in traumatic infections, such as keratitis (Burges et al. 1987; Pauzner et al. 1997; Mathews and Maharajan 1999; Joseph et al. 2012). Otherwise species may cause invasive infections in immunocompromised patients (Aquino et al. 1995), with risk factors including aplastic anemia (Lasala et al. 2005; Adler et al. 2006) and hematopoietic stem cell transplant (HSCT) (Togitani et al.
2007; Ritter et al. 2013). Recently, E. rostratum was implicated in a large meningitis outbreak that was traced back to contaminated steroid injections (Lyons et al. 2012; Gade et al. 2013; Lockhart et al. 2013; Smith et al. 2013). The species can be identified morphologically using nutritionally deficient media in which its morphology is most pronounced. Colonies are usually gray or black, hairy, and spreading. Conidiophores are brown to olivaceous brown in color, simple, thick, and smooth walled. Conidia are fusiform, cylindrical, or obclavate. Sequencing the rDNA ITS region is sufficient for routine identification, and a real-time assay for rapid identification of $E$. rostratum has been developed (Guerra et al. 2013; Zhao et al. 2013).

\section{Falciformispora (Pleosporales: Trematosphaeriaceae)}

Two species producing ascigerous fruit bodies formerly classified in Leptosphaeria belong to this genus, namely, Falciformispora senegalensis and Falciformispora tompkinsii, both agents of human mycetoma (Ahmed et al. 2014). Colonies are radially folded, grayish green, with brown exudate on the colony surface; the reverse is dark brown, with dark-brown pigment diffusing into the agar, and conidia absent. Ascomata appear on the agar surface after months of incubation, black, solitary, (sub)spherical, and thick walled. Asci are clavate, rounded at the apex, bitunicate, and contain eight ascospores. Ascospores are ellipsoidal, four-septate, with constrictions at the septa; the second cell from the top is the largest, leading to widening of the thin sheath that surrounds the ascospore.

\section{Fonsecaea (Chaetothyriales: Herpotrichiellaceae)}

The clinically relevant members of this genus comprise three closely related species, F. pedrosoi, F. monophora, and Fonsecaea nubica, all causing human chromoblastomycosis. Saprobic Fonsecaea species are found in the environment as degraders of plant debris (Najafzadeh et al. 2010b). The disease may be acquired by accidental inoculation of plant debris carrying 
A. Chowdhary et al.

Fonsecaea cells. In vitro, colonies are dark olivaceous, velvety to cottony, and with restricted expansion growth. Budding cells are absent, but additional phialides occur on nutritionally deficient media. Conidiophores are poorly differentiated, pale to dark olivaceous, and have apically clustered, cylindrical denticles bearing conidia. Conidia are $0-1$ septate, arising singly or in short, branched chains. Species distinction requires sequencing of the ITS region, or alternatively a specific PCR for identification of Fonsecaea species is available (Gunde-Cimerman et al. 2000; Najafzadeh et al. 2010a).

\section{Hortaea (Capnodiales: Capnodiaceae)}

$H$. werneckii is the causative agent of tinea nigra, a visible colonization of the palm on one or both hands, sometimes also affecting the sole. H. werneckii is a halophilic fungus occurring at coastal areas in (sub)tropical climates, where it lives in natural or man-made saltpans (Zalar et al. 1999; Uezato et al. 2006); one strain was recovered from house dust. Colonies in vitro have restricted growth and are tar black, smooth, slimy, and glistening. Hyphae are wide, densely septate at maturation, becoming dark brown and thick walled locally. Conidia are produced from wide annellated zones and are hyaline, later turning pale olivaceous, ellipsoidal, often developing a thick median septum; and they reproduce by budding. Conidia often get converted into clumps of chlamydospore-like cells. Molecular identification of $H$. werneckii is possible with rDNA ITS sequencing (Abliz et al. 2004).

\section{Knufia (Chaetothyriales: Herpotrichiellaceae)}

One species of this genus, Knufia epidermidis, formerly known as Coniosporium epidermidis, has been reported from human skin ( $\mathrm{Li}$ et al. 2008). Symptoms are very mild, possibly just colonization occurs in many cases. Colonies grow slowly, velvety, and black to blackish brown. Hyphae are regularly and densely septate, profusely branched at nearly right angles, and are olivaceous black or dark brown. Cells gradually swell and develop thick walls at maturity. Conidia formed by liberation of arthric cells swell to become ellipsoidal or nearly spherical. The species can be recognized by ITS sequencing.

\section{Madurella (Sordariales: Chaetomiaceae)}

Madurella is the classical agent of human mycetoma, which is a subcutaneous infection characterized by necrosis and draining sinuses. The fungus presents in the form of compact grains. In vitro, sporulation is absent or very scant. At present, three molecular siblings are recognized, all being endemic in arid climate zones, particularly in northeastern Africa (de Hoog et al. 2012). Madurella mycetomatis is the prevalent species. Phylogenetically, the species cluster as a part of the ascomycete genus Chaetomium (de Hoog et al. 2013). Madurella grisea is unrelated and is now classified in Trematosphaeria (Pleosporales) (Ahmed et al. 2014).

\section{Medicopsis (Pleosporales: Trematosphaeriaceae)}

A genus with a single species, formerly known as Pyrenochaeta romeroi, is a rare agent of human mycetoma (Ahmed et al. 2014). The natural habitat of this fungus is unknown. Colonies are grayish green and velvety, producing rather broad hyphae. Pycnidia are black, solitary with short dark brown to black setae, and are produced after prolonged incubation. Conidiophores are phialidic, smooth walled, hyaline, ampulliform, and produce unicellular, hyaline, and cylindrical to ellipsoidal conidia.

\section{Neoscytalidium (Dothideales: Dothioraceae)}

Neoscytalidium dimidiatum causes superficial, cutaneous, and ungual infections in humans in tropical climate zones (Gentles and Evans 1970), and is now known to be a common pathogen causing onychomycosis and tinea pedis (Gugnani et al. 1989; Lacaz et al. 1999; Padin et al. 2005; Ungpakorn 2005). The species is found in the soil and vegetation, and causes diseases of deciduous trees. $N$. dimidiatum is distinguished from dermatophytes by its characteristic sinuous, irregular hyphal appearance 
on direct microscopy of cutaneous specimens, its fast-growing, black, and hairy colonies, and its sensitivity to cycloheximide (Tan et al. 2008). Chains of arthroconidia with brown walls are produced in abundance in the aerial mycelium; many have two cells separated by a thick septum. Smooth- and thick-walled pycnidia may be formed after $2 \mathrm{wk}$, showing typical 1-2 septate conidia, which develop a darkened central cell on liberation. ITS sequencing is sufficient for identification (Tan et al. 2008; Madrid et al. 2009).

\section{Ochroconis (Venturiales: Sympoventuriaceae)}

The species from this genus have been isolated worldwide from soil, water, and nutritionally poor environments. About 20 species are known in the genus, many of which are rare and presently are not available for sequencing (Boggild et al. 2006; Samerpitak et al. 2014). Human infections are mainly caused by Ochroconis musae and usually remain superficial, because species of the genus do not grow above $35^{\circ} \mathrm{C}$ (Samerpitak et al., in press). Colonies are brown olive with a velvety texture, and the reverse is often rust brown. Microscopically, species are characterized by brown hyphae with small, unbranched conidiophores bearing apical collarette-like denticles arranged sympodially, and ellipsoidal conidia with one to three transverse septa (de Hoog et al. 2000). For molecular identification, sequencing of ITS and D1/D2 regions of LSU rDNA can be used.

\section{Phaeoacremonium (Diaporthales: Togniniaceae)}

The genus Phaeoacremonium (Crous et al. 1996) contains species that occur in plant debris and generally are known to cause plant diseases; some cause subcutaneous infections in humans when introduced traumatically. Opportunistic diseases are particularly seen with Phaeoacremonium parasiticum, whereas Phaeoacremonium alvesii, Phaeoacremonium amstelodamense, Phaeoacremonium griseorubrum, Phaeoacremonium krajdenii, Phaeoacremonium rubrigenum, Phaeoacremonium inflatipes, Phaeoacremonium tardicrescens, and Phaeoacremonium venezuelense (Padhye et al. 1998; Guarro et al. 2003; Mostert et al. 2005, 2006) are mainly observed as causes of mycetoma. Occasional cases of onychomycosis and arthritis have also been reported (Torstrick et al. 1979; Reyes and Buchman 1986; Fincher et al. 1988; Guarro et al. 2003; Farina et al. 2007). Morphologically, the Phaeoacremonium colonies are grayish olivaceous to grayish brown in color, expanding, wooly to cottony, and often produce bright pigments into the agar. Conidiophores are generally erect, stiff, cylindrical, and irregularly branched. The phialides are cylindrical, tapering at the apex, showing a wide diversity of conidial shapes including ellipsoidal, obovoidal, cylindrical, or allantoid. Sequencing of ITS regions of rDNA was able to detect and identify species of Phaeoacremonium (Aroca and Raposo 2007), although sequencing of the $\beta$-tubulin gene is generally used in taxonomy (Mostert et al. 2005; Crous et al. 2006).

\section{Phialophora (Chaetothyriales: Herpotrichiellaceae)}

Members of the genus may cause subcutaneous or occasionally disseminated (Hofmann et al. 2005), chromoblastomycosis-like infections with hyperproliferation of host tissue. Infections by $P$. verrucosa can be destructive and refractory to therapy (Saunte et al. 2011). Other species, such as Phialophora europaea are colonizers of human skin and nail without causing major symptoms (Gao et al. 2013). The natural habitat of most species is unknown, although some are regularly found in bathing facilities and similar humid, nutritionally poor environments. In vitro, the species have velvety, olivaceous colonies and produce conidia from simple, flask-shaped, to cylindrical phialides. Conidia are produced in slimy balls through more or less pronounced collarettes. Species identification is possible by ITS sequencing.

\section{Phoma (Pleosporales: Pleosporaceae)}

Phoma species are ubiquitous saprobes on plant material (de Hoog et al. 2000) and have been occasionally associated with human infections 
A. Chowdhary et al.

including subcutaneous infection, keratitis, or onychomycosis that are traumatically acquired (Arrese et al. 1997; Zaitz et al. 1997; Rishi and Font 2003; Errera et al. 2008; Tullio et al. 2010). Phoma species produce colonies with spherical, solitary dark pycnidia, usually each with a single or sometimes with several ostioles. Phialides are arranged as the innermost wall of the fruit body and produce abundant unicellular, ellipsoidal, or cylindrical conidia, which are hyaline to pale colored and ooze out in large slimy masses. For identification of species, ITS sequencing is sufficient.

\section{Pseudochaetosphaeronema (Pleosporales: Lentitheciaceae)}

The single species, Pseudochaetosphaeronema larense (formerly Chaetosphaeronema larense), is known in this genus. The fungus was described from a case of human mycetoma. Colonies grow slowly, velvety, and gray. Pycnidia are produced after several months of incubation and they are black, solitary, and obpyriform with long necks. Conidia are hyaline, unicellular, and subspherical to ellipsoidal. Conidiophores are ampulliform, hyaline, and phialidic. For identification of species, ITS sequencing is sufficient.

\section{Pyrenochaeta (Pleosporales: Cucurbitaceae)}

Pyrenochaeta is a genus of Coelomycetes with conidial fruit bodies covered by setae. Recently, the genus has been found to be phylogenetically diverse and most species have been reclassified into other genera. Only Pyrenochaeta keratinophila and Pyrenochaet unguis-hominis, agents of superficial infections, have been retained in the genus. The species are characterized by the presence of rapidly growing flat, velvety, or floccose colonies producing dark olive-gray aerial hyphae with olivaceous black reverse. Pycnidia are usually solitary, spherical to subspherical, ostiolate, setose, and brown in color, and are produced after 2 to $3 \mathrm{wk}$. Abundant dark brown setae are present all around the ostiole usually tapering at the tip. Conidia are produced from ampulliform phialides lining the innermost pycnidial wall and are hyaline, one celled, and ellipsoidal to bacilliform. P. romeroi and Pyrenochaet mackinnonii were accommodated in the new genera Medicopsis and Nigrograna, respectively, based on the analysis of ITS, D1/D2, $\beta$ tubulin, and chitin synthase 1 gene sequences (de Gruyter et al. 2009).

\section{Rhinocladiella (Chaetothyriales: Herpotrichiellaceae)}

The genus presently contains four clinically relevant species, namely, $R$. aquaspersa, $R$. mackenziei, Rhinocladiella basitona, and Rhinocladiella similis. Two of these, $R$. basitona and $R$. similis, are rare agents of skin infections. $R$. aquaspersa is one of the agents of chromoblastomycosis. R. mackenziei is one of the most notorious causative agents of cerebral phaeohyphomycosis, often occurring in otherwise healthy individuals (del Palacio-Hernanz et al. 1989; Kanj et al. 2001; de Gruyter et al. 2009; González et al. 2013); it is strictly endemic to the Middle East, and its natural habitat is presently unknown. Rhinocladiella species have dark olivaceous-brown colonies producing conidiophores, which are pale to dark brown, somewhat or clearly differentiated from the mycelium, suberect, and mostly unbranched. Conidia arise sympodially on denticles and are hyaline to brown, one celled, and smooth walled. R. mackenziei is characterized by its stout conidiophores and brown, thick-walled conidia. Definitive identification of the species requires sequencing of ITS and/or D1/D2 regions of the LSU rDNA gene (Jabeen et al. 2011).

\section{Trematosphaeria (Pleosporales: Trematosphaeriaceae)}

This coelomycete, previously classified as Madurella grisea, occasionally has been reported to cause human subcutaneous infections (Ahmed et al. 2014), but is mostly found in water. Colonies are dark gray at the center, becoming faint toward the margin; the reverse is dark brown to black. Colonies on oatmeal agar are flat and olivaceous brown to black. Environmental isolates of Trematosphaeria grisea grow 
rapidly with expanding, gray conidial fruit bodies ( pycnidia) and are produced only after prolonged incubation. Pycnidia are globose with a wide opening from which slimy conidial masses emerge. Conidia are hyaline to pale brown, unicellular, and clavate to ellipsoidal. Conidiophores are hyaline and rostrate with a very short and hardly detectable collarette.

\section{Veronaea (Chaetothyriales: Herpotrichiellaceae)}

The genus Veronaea contains one clinical species, namely, Veronaea botryosa, which is readily recognizable by its morphology (de Hoog et al. 2000). V. botryosa probably is an environmental fungus but its ecological niche is still unknown. Most human infections are disseminated, leading to secondary, dry eruptions with significant hypergrowth in the infected skin (Bonifaz et al. 2013). Cutaneous lesions are nodular and subcutaneous, resembling those of chromoblastomycosis, with muriform cells in tissue; a strong tendency to disseminate is the clinical hallmark of this fungus (Ayadi et al. 1995; Chen et al. 2006; Sang et al. 2011; Bonifaz et al. 2013). The colonies are usually fast growing, velvety to lanose, and grayish brown in color. The large, erect conidiophores with sympodial, one-septate conidia on flat scars make this fungus unmistakable. Sequencing of the ITS region is applicable for the precise identification of this fungus (Badali et al. 2013).

\section{Verruconis (Venturiales, Sympoventuriaceae)}

This is a small group of fungi found in heated environments, such as chicken coop litter and the effluents of thermal nuclear reactors. In warmblooded animals, including wild ones, brain infection is primarily noted; human patients are almost invariably immunocompromised. The exact route of infection is unclear, but inhalation of conidia has been hypothesized (Bravo and Ngamy 2004). The fungus produces rust brown colonies and has short conidiophores, which have only $1-3$ open-ended conidial scars. The conidia are hyaline, clavate, and two celled. Verruconis is remote from other fungi and can eas- ily be recognized by ITS sequencing (Jenney et al. 1998; Malani et al. 2001; Fukushima et al. 2005; Hollingsworth et al. 2007).

\section{ROUTINE DIAGNOSIS OF BLACK FUNGI}

Distinctive histopathologic features are observed depending on the clinical form of the disease. However, different etiological agents may produce identical pathologic features. Clinical diagnosis of chromoblastomycosis is confirmed by the presence of single or clustered thick-walled brown cells intracellularly within macrophages and lying freely in the dermis as the characteristic sclerotic cells (muriform cells, Medlar bodies) (de Hoog et al. 2000). Tissue shows hyperkeratosis with pseudoepitheliomatous hyperplasia with a lichenoid granulomatous inflammatory pattern. In (sub)cutaneous phaeohyphomycosis, necrosis rather than hyperproliferation is present, with brown hyphal elements or yeast-like cells in 20\% $\mathrm{KOH}$-digested tissue (Kwon-Chung and Bennett 1992). The brown pigment in the walls of fungal elements may be visible in haemotoxylin and eosinstained tissue sections. Skin infections by $A$. infectoria often yield hyaline yeast-like elements rather than dark hyphae. In cerebral phaeohyphomycosis, a $\mathrm{KOH}$ preparation of pus from the lesion may also show lightly pigmented hyphae. Fontana-Masson staining helps to identify the melanized nature of the fungus.

Isolation of the fungus is recommended to confirm the diagnosis. Initial growth of black fungi is on Sabouraud's glucose agar. Often other media are recommended to enhance morphology and sporulation: potato dextrose agar for slow-growing Chaetothyriales, and nutritionally poor media for many Pleosporales, which show rapid expanding growth. In coelomycetes, fruit bodies are often produced after prolonged incubation, whereas in others sporulation may remain absent. Rapid identification by sequencing is therefore recommended; ITS mostly provides sufficient resolution down to the species level.

No specific clinical or radiological features are available for the diagnosis of cerebral phaeohyphomycosis. A computerized tomography 
A. Chowdhary et al.

scan of the cranium often reveals a unilateral, well-circumscribed mass lesion in the frontal lobe (Jayakeerthi et al. 2004; Garg et al. 2007). Abscesses may be single or multiple and localized within the cerebral cortex (Garg et al. 2007). Purulent meningitis, with or without brain abscess, may also be seen (Walz et al. 1997). For definite diagnosis and distinction from other brain disorders, biopsy specimens are needed.

\section{ANTIFUNGAL SUSCEPTIBILITY TESTING AND THERAPY}

The majority of clinical experiences with black molds represent isolated cases or small series of infections with different fungi. Therefore, evidence-based algorithms for specific treatments are not robust, but there are several important surgical and medical principles to consider.

Surgery can be an essential feature in management of certain phaeomycosis. For a subcutaneous cyst, complete removal of the encapsulated structure can be curative. However, care must be taken to not leak contents in the wound, and a single aspiration of a cyst or systemic antifungal agents alone for treatment are not optimal. Furthermore, ulcerative lesions of the skin and soft tissue without a cyst can be effectively managed with debridement, such as the use of Mohs-type micrographic surgery, which can achieve low recurrence rate and maximal preservation of host tissue. In brain abscesses, surgical debulking of abscess with adjunctive medical therapy is recommended for cure because complete debridement/removal of abscess is generally not possible. Although occasionally medical therapy alone is successful, it is likely that a combined medical-surgical therapeutic approach is preferred, and medical treatment only should be reserved for patients with multiple abscesses and for patients for whom surgery is contraindicated. Eumycetomas in the extremities can be extremely difficult to manage. Because of their indolent nature, scarring, fistula formation, and bone involvement, the ability to obtain disease-free tissue margins may be difficult via surgery, and medical therapy for these infections may be the best option.
Medical therapy with antifungal agents is based on in vitro and in vivo evidence for antifungal drug activity (McGinnis et al. 1997; Espinel-Ingroff 1998a,b; McGinnis and Pasarell 1998), but is generally not genus and species specific. In fact, for these invasive fungal infections, it is reasonable to check in vitro antifungal susceptibility results of the strain to help with antifungal drug management. In vitro antifungal susceptibility data for the melanized fungi have been increasingly reported and generally reveals that most species are susceptible to triazoles. However, it is important to note that there are no clinical break points or randomized clinical trials available to evaluate efficacy of antifungal agents in this group of fungi.

With regard to the present antifungal drug classes, there are several general comments for their use in phaeohyphomycosis. First, polyene drugs show modest antifungal activity in vitro and have been used successfully in some cases of disseminated disease. However, occasional resistance is found in some species, such as strains of Curvularia, Exophiala, and R. mackenziei. Second, flucytosine has variable activity against dematiaceous fungi, and its use should be guided by in vitro susceptibility testing and should always be used in combination with another agent(s) secondary to rapid development of drug resistance. Third, terbinafine use should also be guided by in vitro antifungal susceptibility testing of the specific isolate (Clancy et al. 2000; Queiroz-Telles et al. 2009). Finally, the echinocandins do have in vitro antifungal activity against some dematiaceous fungi (Del Poeta et al. 1997; Espinel-Ingroff 1998b, 2003), but clinical experience with this class of antifungal agents remains minimal and their use will be most commonly considered in disseminated during combination therapy.

The azoles have been the primary agents for phaeohyphomycosis because of excellent in vitro activity, safety in long-term use, and clinical experience. Itraconazole has been the best studied with a reported success rate of $60 \%$ (Sharkey et al. 1990). The European Society of Clinical Microbiology and Infectious Diseases and European Confederation of Medical Mycology Joint Guidelines for the diagnosis and manage- 
ment of systemic phaeohyphomycosis suggests oral itraconazole to be the drug of choice for most situations given the extensive clinical experience with this agent (Chowdhary et al. 2014b). However, voriconazole is preferred because of better tolerability, safety, and the availability of an intravenous formulation, and it is specifically recommended for central nervous system infections as a result of its ability to achieve good cerebrospinal fluid and brain tissue levels, unlike itraconazole (Chowdhary et al. $2014 \mathrm{~b}$ ). Both of the extended-spectrum triazoles, voriconazole and posaconazole, have also been reported to achieve excellent outcomes (McGinnis et al. 1997; Espinel-Ingroff, 1998a,b; Perfect et al. 2003; Negroni et al. 2004, 2005; Fothergill et al. 2009), but, in disseminated infection with a serious underlying disease, failures occur secondary to direct drug resistance and biofilm formation on foreign bodies and/ or progression of underlying diseases or cancer (Ben-Ami et al. 2009). The length of treatment remains empirical for these infections and must be judged individually. However, these infections generally need at least several months of drug exposure. In life-threatening central nervous system infections, there has been enthusiasm for using combination antifungal therapy along with surgery because there is some supportive in vitro additive or synergistic data against dematiaceous fungi (McGinnis and $\mathrm{Pa}$ sarell 1998; Clancy et al. 2000). Because randomized studies to prove efficacy are unlikely, it is reasonable to consult experts to help in the therapeutic strategies against these relatively rare and fatal brain abscesses and disseminated infections.

\section{CONCLUDING REMARKS}

Melanized fungi in general are underestimated as etiologic agents of varied clinical entities primarily attributed to difficulties in classical identification owing to often slow growth and poor morphology. However, this scenario has changed considerably with the introduction of molecular diagnostics. Nearly all species can confidently be recognized by the rDNA ITS barcoding marker. Also, a majority of the mela-
Black Molds and Yeasts Pathogenic to Humans

nized fungi are associated with non-life-threatening infections in the clinical lab and are generally not reported. However, despite their rarity, they are highly relevant because of their potential to infect and kill apparently healthy individuals. Chronic CNS infections may remain unnoticed for a long time, or are misdiagnosed as tumors, and then take a fatal course. Disseminated and (sub)cutaneous infections, such as chromoblastomycosis, are recalcitrant to therapy and may relapse despite the fungus' in vitro susceptibility to the antifungals. Colonizers of skin and cystic fibrosis lungs are much more frequent than generally supposed. The treatment options for melanized fungi are generally limited because of the efficacy of antifungal agents and limitations of surgical interventions. Novel and rapid diagnostic methods are being developed and are likely to change the landscape of infectious molds considerably.

\section{REFERENCES}

Abbott SP, Sigler L, McAleer R, McGough DA, Rinaldi MG, Mizell G. 1995. Fatal cerebral mycoses caused by the ascomycete Chaetomium strumarium. J Clin Microbiol 33: 2692-2698.

Abliz P, Fukushima K, Takizawa K, Nishimura K. 2004. Identification of pathogenic dematiaceous fungi and related taxa based on large subunit ribosomal DNA D1/D2 domain sequence analysis. FEMS Immunol Med Microbiol 40: $41-49$.

Adler A, Yaniv I, Samra Z, Yacobovich J, Fisher S, Avrahami G, Levy I. 2006. Exserohilum: An emerging human pathogen. Eur J Clin Microbiol Infect Dis 25: $247-$ 253.

Ahmed SA, van de Sande WWJ, Stevens DA, Fahal A, van Diepeningen A, Menken SBJ, de Hoog GS. 2014. Revision of agents of black-grain eumycetoma in the order Pleosporales. Persoonia (in press).

Al-Mohsen IZ, Sutton DA, Sigler L, Almodovar E, Mahgoub N, Frayha H, Al-Hajjar S, Rinaldi MG, Walsh TJ. 2000. Acrophialophora fusispora brain abscess in a child with acute lymphoblastic leukemia: Review of cases and taxonomy. J Clin Microbiol 38: 4569-4576.

Al-Tawfiq JA, Boukhamseen A. 2011. Cerebral phaeohyphomycosis due to Rhinocladiella mackenziei (formerly Ramichloridium mackenziei): Case presentation and literature review. J Infect Public Health 4: 96-102.

Ameen M. 2009. Chromoblastomycosis: Clinical presentation and management. Clin Exp Dermatol 34: 849854.

Aquino VM, Norvell JM, Krisher K, Mustafa MM. 1995. Fatal disseminated infection due to Exserohilum rostratum in a patient with aplastic anemia: Case report and review. Clin Infect Dis 20: 176-178. 
A. Chowdhary et al.

Aroca A, Raposo R. 2007. PCR-based strategy to detect and identify species of Phaeoacremonium causing grapevine diseases. Appl Environ Microbiol 73: 2911-2918.

Arranz Sánchez DM, de la Calle MC, Martín-Díaz MA, Flores CR, González-Beato MJ, Pinto PH, Díaz Díaz RM. 2006. Subcutaneous mycosis produced by Aureobasidium pullulans in a renal transplant recipient. J Eur Acad Dermatol Venereol 20: 229-230.

Arrese JE, Pierard-Franchimont C, Pierard GE. 1997. Unusual mould infection of the human stratum corneum. J Med Vet Mycol 35: 225-227.

Aru A, Munk-Nielsen L, Federspiel BH. 1997. The soil fungus Chaetomium in the human paranasal sinuses. Eur Arch Otorhinolaryngol 254: 350-352.

Ayadi A, Huerre MR, de Bièvre C. 1995. Phaeohyphomycosis caused by Veronaea botryosa. Lancet 346: 1703-1704.

Badali H, Gueidan C, Najafzadeh MJ, Bonifaz A, van den Ende AH, de Hoog GS. 2008. Biodiversity of the genus Cladophialophora. Stud Mycol 61: 175-191.

Badali H, Najafzadeh MJ, van Esbroeck M, van den Enden E, Tarazooie B, Meis JF, de Hoog GS. 2010. The clinical spectrum of Exophiala jeanselmei, with a case report and in vitro antifungal susceptibility of the species. Med Mycol 48: 318-327.

Badali H, Yazdanparast SA, Bonifaz, Mousavi B, de Hoog GS, Klaassen CH, Meis JF. 2013. Veronaea botryosa: Molecular identification with amplified fragment length polymorphism (AFLP) and in vitro antifungal susceptibility. Mycopathologia 175: 505-513.

Barron MA, Sutton DA, Veve R, Guarro J, Rinaldi M, Thompson E, Cagnoni PJ, Moultney K, Madinger NE. 2003. Invasive mycotic infections caused by Chaetomium perlucidum, a new agent of cerebral phaeohyphomycosis. J Clin Microbiol 41: 5302-5307.

Bava AJ, Fayad A, Céspedes C, Sandoval M. 2003. Fungal peritonitis caused by Bipolaris spicifera. Med Mycol 41: 529-531.

Ben-Ami R, Lewis RE, Raad II, Kontoyiannis DP. 2009. Phaeohyphomycosis in a tertiary care cancer center. Clin Infect Dis 48: 1033-1041.

Boggild AK, Poutanen SM, Mohan S, Ostrowski MA. 2006. Disseminated phaeohyphomycosis due to Ochroconis gallopavum in the setting of advanced HIV infection. Med Mycol 44: 777-782.

Bonifaz A, Davoudi MM, de Hoog GS, Padilla-Desgarennes C, Vázquez-González D, Navarrete G, Meis JF, Badali H. 2013. Severe disseminated phaeohyphomycosis in an immunocompetent patient caused by Veronaea botryosa. Mycopathologia 175: 497-503.

Borelli D. 1980. Causal agents of chromoblastomycosis (Chromomycetes). In Proceedings of the 5th International Conference on Mycoses, pp. 335-340. Pan American Health Organization, Venezuela.

Bravo LO, Ngamy V. 2004. Ochroconis gallopavum and Mycobacterium avium intracellulare in an immunocompetent patient. Chest 126: $975 \mathrm{~S}$.

Burges GE, Walls CT, Maize JC. 1987. Subcutaneous phaeohyphomycosis caused by Exserohilum rostratum in an immunocompetent host. Arch Dermatol 123: 13461350.
Caporale NE, Calegari L, Perez D, Gezuele E. 1996. Peritoneal catheter colonization and peritonitis with Aureobasidium pullulans. Perit Dial Int 16: 97-98.

Carter E, Boudreaux C. 2004. Fatal cerebral phaeohyphomycosis due to Curvularia lunata in an immunocompetent patient. J Clin Microbiol 42: 5419-5423.

Chang X, Li R, Yu J, Bao X, Qin J. 2009. Phaeohyphomycosis of the central nervous system caused by Exophiala dermatitidis in a 3-year-old immunocompetent host. J Child Neurol 24: 342-345.

Chawla B, Sharma N, Titiyal JS, Nayak N, Satpathy G. 2010. Aureobasidium pullulans keratitis following automated lamellar therapeutic keratoplasty. Ophthalmic Surg Lasers Imaging 9: 1-3.

Chen YT, Lin HC, Huang CC, Lo YH. 2006. Cutaneous phaeohyphomycosis caused by an itraconazole and amphotericin B resistant strain of Veronaea botryosa. Int J Dermatol 45: 429-432.

Chowdhary A, Randhawa HS, Singh V, Khan ZU, Ahmad S, Kathuria S, Roy P, Khanna G, Chandra J. 2011. Bipolaris hawaiiensis as etiologic agent of allergic bronchopulmonary mycosis: First case in a paediatric patient. Med Mycol 49: $760-765$.

Chowdhary A, Agarwal K, Randhawa HS, Kathuria S, Gaur SN, Najafzadeh MJ, Roy P, Arora N, Khanna G, Meis JF 2012. A rare case of allergic bronchopulmonary mycosis caused by Alternaria alternata. Med Mycol 50: 890-896.

Chowdhary A, Agarwal K, Kathuria S, Gaur SN, Randhawa HS, Meis JF. 2014a. Allergic bronchopulmonary mycosis due to fungi other than Aspergillus: A global overview. Crit Rev Microbiol 40: 30-48.

Chowdhary A, Meis JF, Guarro J, de Hoog GS, Kathuria S, Arendrup MC, Arikan-Akdagli S, Akova M, Boekhout T, Caira M, et al. 2014b. ESCMID and ECMM joint guidelines for the diagnosis and management of systemic phaeohyphomycosis: Diseases caused by black fungi. Clin Microbiol Infect Dis 20: 47-75.

Clancy CJ, Wingard JR, Nguyen MH. 2000. Subcutaneous phaeohyphomycosis in transplant recipients: Review of the literature and demonstration of in vitro synergy between antifungal agents. Med Mycol 38: 169-175.

Clark EC, Silver SM, Hollick GE, Rinaldi MG. 1995. Continuous ambulatory peritoneal dialysis complicated by Aureobasidium pullulans peritonitis. Am J Nephrol 15: 353-355.

Crous PW, Gams W, Wingfield MJ, Van Wyk PS. 1996. Phaeoacremonium gen. nov. associated with wilt and decline diseases of woody hosts and human infections. Mycologia 88: 786-796.

Crous PW, Slippers B, Wingfield MJ, Rheeder J, Marasas WF, Philips AJ, Alves A, Burgess T, Barber P, Groenewald JZ. 2006. Phylogenetic lineages in the Botryosphaeriaceae. Stud Mycol 55: 235-253.

Cunha D, Amaro C, Vieira MR, Martins Mda L, Maduro AP, Inácio J, Afonso A, Pinto GM, Cardoso J. 2012. Phaeohyphomycosis caused by Alternaria infectoria presenting as multiple vegetating lesions in a renal transplant patient. Rev Iberoam Micol 29: 44-46.

da Cunha KC, Sutton DA, Fothergill AW, Cano J, Gené J, Madrid H, de Hoog GS, Crous PW, Guarro J. 2012a. Diversity of Bipolaris species in clinical samples in the 
United States and their antifungal susceptibility profiles. J Clin Microbiol 50: 4061-4066.

da Cunha KC, Sutton DA, Gené J, Capilla J, Cano J, Guarro J. 2012b. Molecular identification and in vitro response to antifungal drugs of clinical isolates of Exserohilum. Antimicrob Agents Chemother 56: 4951-4954.

De Gruyter J, Aveskamp MM, Woudenberg JHC, Verkley GJ, Groenewald JZ, Crous PW. 2009. Molecular phylogeny of Phoma and allied anamorph genera: Towards a reclassification of the Phoma complex. Mycol Res 113: 508-519.

de Hoog GS, Vitale RG. 2007. Bipolaris, Exophiala, Scedosporium, Sporothrix and other dematiaceous fungi. In Manual of clinical microbiology, 9th ed. (ed. Murray PR, Baron EJ, Jorgenson JH, Landry ML, Pfaller MA), Vol. 2, pp. 1898-1917. ASM, Washington, DC.

de Hoog GS, Guarro J, Gené J, Figueras MJ. 2000. Atlas of clinical fungi, 2 nd ed. Centraalbureau voor Schimmelcultures, Amsterdam, 1126 pp.

de Hoog GS, Vicente V, Caligiorne RB, Kantarcioglu S, Tintelnot K, Gerrits van den Ende AHG, Haase G. 2003. Species diversity and polymorphism in the Exophiala spinifera clade containing opportunistic black yeast-like fungi. J Clin Microbiol 41: 4767-4778.

de Hoog GS, van Diepeningen AD, Mahgoub ES, van de Sande WWJ. 2012. New species in Madurella, causative agents of black-grain mycetoma. J Clin Microbiol 50: 988-994.

de Hoog GS, Ahmed SA, Najafzadeh MJ, Sutton DA, Keisari MS, Fahal AH, Eberhart U, Verkley GJ, Xin L, Stielow B, et al. 2013. Possible new routes of infection of human eumycetoma. PLoS Negl Trop Dis 7: e2229.

Delfino D, de Hoog S, Polonelli L, Benecchi M, Fanti F, Galatioto S, Manti G, Cusumano V. 2006. Survival of a neglected case of brain abscess caused by Cladophialophora bantiana. Med Mycol 44: 651-654.

Del Palacio-Hernanz A, Moore MK, Campbell CK, Del Palacio-Medel A, Del Castillo-Cantero R. 1989. Infection of the central nervous system by Rhinocladiella atrovirens in a patient with acquired immunodeficiency syndrome. J Med Vet Mycol 27: 127-130.

Del Poeta M, Schell WA, Perfect JR. 1997. In vitro antifungal activity of pneumocandin L-743,872 against a variety of clinically important moulds. Antimicrob Agents Chemother 41: 1835-1836.

De Lucca AJ. 2007. Harmful fungi in both agriculture and medicine. Rev Iberoam Micol 24: 3-13.

Döğen A, Ilkit M, de Hoog GS. 2013. Black yeast habitat choices and species spectrum on high altitude creosotetreated railway ties. Fungal Biol 117: 692-696.

Ebright JR, Chandrasekar PH, Marks S, Fairfax MR, Aneziokoro A, McGinnis MR. 1999. Invasive sinusitis and cerebritis due to Curvularia clavata in an immunocompetent adult. Clin Infect Dis 28: 687-689.

El-Morsy SM, Khafagy YW, El-Naggar MM, Beih AA. 2010. Allergic fungal rhinosinusitis: Detection of fungal DNA in sinus aspirate using polymerase chain reaction. J Laryngol Otol 124: 152-160.

Errera MH, Barale PO, Nourry H, Zamfir O, Guez A, Warnet JM, Sahel JA, Chaumeil C. 2008. Usefulness of voriconazole in treatment of Phoma glomerata after penetrating injury. J Fr Ophtalmol 31: 62-66.
Espinel-Ingroff A. 1998a. A comparison of in vitro activities of the new triazole SCH56592 and the echinocandins MK 0991(L-743,872) and LY303366 against opportunistic filamentous and dimorphic fungi and yeasts. J Clin Microbiol 36: 2950-2956.

Espinel-Ingroff A. 1998b. In vitro activity of the new triazole voriconazole UK 109,496 against opportunistic filamentous and dimorphic fungi and common and emerging yeast pathogens. J Clin Microbiol 36: 198-202.

Espinel-Ingroff A. 2003. In vitro antifungal activities of anidulafungin and micafungin, licensed agents and the investigational triazole posaconazole as determined by NCCLS methods for 12,052 fungal isolates: Review of the literature. Rev Iberoam Micol 20: 121-136.

Farina C, Gotti E, Mouniee D, Boiron P, Goglio A. 2007. Phaeoacremonium parasiticum subcutaneous infection in a kidney-transplanted patient successfully treated by surgery. Transpl Infect Dis 9: 253-255.

Feng P, Lu Q, Najafzadeh MJ, Gerrits van den Ende AHG, Sun J, Li RY, Xi LY, Vicente VA, Lai W, Lu C, et al. 2014 Cyphellophora and its relatives in Phialophora: Biodiversity and possible role in human infection. Fungal Div 65: $17-45$.

Fincher RM, Fisher JF, Padhye AA, Ajello L, Steele JC Jr. 1988. Subcutaneous phaeohyphomycotic abscess caused by Phialophora parasitica in a renal allograft recipient. J Med Vet Mycol 26: 311-314.

Fothergill AW, Rinaldi MG, Sutton DA. 2009. Antifungal susceptibility testing of Exophiala spp.: A head-to-head comparison of amphotericin $\mathrm{B}$, itraconazole, posaconazole and voriconazole. Med Mycol 47: 41-43.

Fukushima N, Mannen K, Okamoto S, Shinogi T, Nishimoto K, Sueoka E. 2005. Disseminated Ochroconis gallopavum infection in a chronic lymphocytic leukemia: A case report and review of the literature on hematological malignancies. Intern Med 44: 879-882.

Gade L, Scheel CM, Pham CD, Lindsley MD, Iqbal N, Cleveland AA, Whitney AM, Lockhart SR, Brandt ME, Litvintseva AP. 2013. Detection of fungal DNA in human body fluids and tissues during a multistate outbreak of fungal meningitis and other infections. Eukaryot Cell 12: 677683.

Gao LJ, Yu J, Wang DL, Li RY. 2013. Recalcitrant primary subcutaneous phaeohyphomycosis due to Phialophora verrucosa. Mycopathologia 175: 165-170

Garg N, Devi IB, Vajramani GV, Nagarathna S, Sampath S, Chandramouli BA, Chandramuki A, Shankar SK. 2007. Central nervous system cladosporiosis: An account of ten culture-proven cases. Neurol India 55: 282-288.

Gentles JC, Evans GV. 1970. Infection of the feet and nails with Hendersonula toruloidea. Sabouraudia 8: 72-75.

González GM, Rojas OC, González JG, Kang YQ, de Hoog GS. 2013. Chromoblastomycosis caused by Rhinocladiella aquaspersa. Med Mycol Case Rep 2: 148-151.

Guarro J. 1998. Comments on recent human infections caused by ascomycetes. Med Mycol 36: 349-350.

Guarro J, Soler L, Rinaldi MG. 1995. Pathogenicity and antifungal susceptibility of Chaetomium species. Eur J Clin Microbiol Infect Dis 14: 613-618.

Guarro J, Alves SH, Gené J, Grazziotin NA, Mazzuco R, Dalmagro C, Capilla J, Zaror L, Mayayo E. 2003. Two 
A. Chowdhary et al.

cases of subcutaneous infection due to Phaeoacremonium spp. J Clin Microbiol 41: 1332-1336.

Guarro J, Mendiratta DK, De Sequeira H, Rodríguez V, Thamke D, Gomes AM, Shukla AK, Menezes F, Narang P, Roldão Vieira J, et al. 2007. Acrophialophora fusispora: An emerging agent of human mycoses. A report of 3 new clinical cases. Diagn Microbiol Infect Dis 59: 85-88.

Guerra RS, do Nascimento MM, Miesch S, Najafzadeh MJ, Ribeiro RO, Ostrensky A, de Hoog GS, Vicente VA, Boeger WA. 2013. Black yeast biota in the mangrove, in search of the origin of the lethargic crab disease (LCD). Mycopathologia 175: 421-430.

Gugnani HC, Oyeka CA. 1989. Foot infections due to Hendersonula toruloidea and Scytalidium hyalinum in coal miners. J Med Vet Mycol 27: 167-79.

Gunde-Cimerman N, Zalar P, de Hoog GS, Plemenitas A. 2000. Hypersaline waters in salterns-Natural ecological niches for halophilic black yeasts. FEMS Microbiol Ecol 32: $235-240$.

Guppy KH, Thomas C, Thomas K, Anderson D. 1998. Cerebral fungal infections in the immunocompromised host: A literature review and a new pathogen-Chaetomium atrobrunneum: Case report. Neurosurgery 43: $1463-1469$.

Halaby T, Boots H, Vermeulen A, van der Ven A, Beguin H, van Hooff H, Jacobs J. 2001. Phaeohyphomycosis caused by Alternaria infectoria in a renal transplant recipient. $J$ Clin Microbiol 39: 1952-1955.

Harris JE, Sutton DA, Rubin A, Wickes B, de Hoog GS, Kovarik C. 2009. Exophiala spinifera as a cause of cutaneous phaeohyphomycosis: Case study and review of the literature. Med Mycol 47: 87-93.

Hawkes M, Rennie R, Sand C, Vaudry W. 2005. Aureobasidium pullulans infection: Fungemia in an infant and a review of human cases. Diagn Microbiol Infect Dis 51: 209-213.

Hipolito E, Faria E, Alves AF, de Hoog GS, Anjos J, Goncalves T. 2009. Alternaria infectoria brain abscess in a child with chronic granulomatous disease. Eur J Clin Microbiol Infect Dis 28: 377-380.

Ho MH-M, Castañeda RF, Dugan FM, Jong SC. 1999. Cladosporium and Cadophialophora in culture: Descriptions and an expanded key. Mycotaxon 72: 115-157.

Hofmann H, Choi S-M, Wilsmann-Theis D, Horré R, Bieber T, de Hoog GS. 2005. Phialophora verrucosa causing invasive chromoblastomycosis and sinusitis in a child from northern Africa. Mycoses 48: 456-461.

Hollingsworth JW, Shofer S, Zaas A. 2007. Successful treatment of Ochroconis gallopavum infection in an immunocompetent host. Infection 35: 367-369.

Horré R, de Hoog GS. 1999. Primary cerebral infections by melanized fungi: A review. Stud Mycol 43: 176-193.

Jabeen K, Farooqi J, Zafar A, Jamil B, Mahmood SF, Ali F, Saeed N, Barakzai A, Ahmed A, Khan E, et al. 2011. Rhinocladiella mackenziei as an emerging cause of cerebral phaeohyphomycosis in Pakistan: A case series. Clin Infect Dis 52: 213-217.

Jayakeerthi SR, Dias M, Nagarathna S, Anandh B, Mahadevan A, Chandramuki A. 2004. Brain abscess due to Cladophialophora bantiana. Indian J Med Microbiol 22: 193-195.
Jenney A, Maslen M, Bergin P, Tang SK, Esmore D, Fuller A. 1998. Pulmonary infection due to Ochroconis gallopavum treated successfully after orthotopic heart transplantation. Clin Infect Dis 26: 236-237.

Joseph NM, Kumar MA, Stephen S, Kumar S. 2012. Keratomycosis caused by Exserohilum rostratum. Indian J Pathol Microbiol 55: 248-249.

Joshi A, Singh R, Shah MS, Umesh S, Khattry N. 2010. Subcutaneous mycosis and fungemia by Aureobasidium pullulans: A rare pathogenic fungus in a post allogeneic BM transplant patient. Bone Marrow Transplant 45: $203-$ 204.

Kaczmarski EB, Liu Yin JA, Tooth JA, Love EM, Delamore IW. 1986. Systemic infection with Aureobasidium pullulans in a leukaemic patient. J Infect 13: 289-291.

Kanj SS, Amr SS, Roberts GD. 2001. Ramichloridium mackenziei brain abscess: Report of two cases and review of the literature. Med Mycol 39: 97-102.

Kantarcioglu AS, de Hoog GS. 2004. Infection of the central nervous system by melanized fungi: A review of cases presented between 1999 and 2004. Mycoses 47: 4-13.

Kutleša M, Mlinarić-Missoni E, Hatvani L, Voncina D, Simon S, Lepur D, Baršić B. 2012. Chronic fungal meningitis caused by Aureobasidium proteae. Diagn Microbiol Infect Dis 73: 271-272.

Kwon-Chung KJ, Bennett JW. 1992. Medical mycology. Lea \& Febiger, Philadelphia, 861 pp.

Lacaz CS, Pereira AD, Heins-Vaccari EM, Cuce LC, Benatti C, Nunes RS, de Melo NT, de Freitas-Leite RS, Hernández-Arriagada GL. 1999. Onychomycosis caused by Scytalidium dimidiatum: Report of two cases. Review of the taxonomy of the synanamorph and anamorph forms of this coelomycete. Rev Inst Med Trop Sao Paulo 41: 319323.

Lasala PR, Smith MB, McGinnis MR, Sackey K, Patel JA, Qiu S. 2005. Invasive Exserohilum sinusitis in a patient with aplastic anemia. Pediatr Infect Dis J 24: 939-941.

Lesire V, Hazouard E, Dequin PF, Delain M, Therizol-Ferly M, Legras A. 1999. Possible role of Chaetomium globosum in infection after autologous bone marrow transplantation. Intensive Care Med 25: 124-125.

Li DM, de Hoog GS. 2009. Cerebral phaeohyphomycosisA cure at what lengths? Lancet Infect Dis 9: 376-383.

Li DM, de Hoog GS, Saunte DM, Gerrits van den Ende AHG, Chen XR. 2008. Coniosporium epidermidis sp. nov., a new species from human skin. Stud Mycol 61: $131-136$.

Li CW, Lee HC, Chang TC, Wan JY, Chen HM, Wu CJ, Lee NY, Chang CM, Lee CC, Ko WC. 2013. Acrophialophora fusispora brain abscess in a patient with acquired immunodeficiency syndrome: A case report and review of the literature. Diagn Microbiol Infect Dis 76: 368-371.

LoCascio G, Ligozzi M, Maccacaro L, Fontana R. 2004. Utility of molecular identification in opportunistic mycotic infections: A case of cutaneous Alternaria infectoria infection in a cardiac transplant recipient. J Clin Microbiol 42: 5334-5336.

Lockhart SR, Pham CD, Gade L, Iqbal N, Scheel CM, Cleveland AA, Whitney AM, Noble-Wang J, Chiller TM, Park BJ, et al. 2013. Preliminary laboratory report of fungal 
infections associated with contaminated methylprednisolone injections. J Clin Microbiol 51: 2654-2661.

Lyons JL, Gireesh ED, Trivedi JB, Bell WR, Cettomai D, Smith BR, Karram S, Chang T, Tochen L, Zhang SX, et al. 2012. Fatal Exserohilum meningitis and central nervous system vasculitis after cervical epidural methyl prednisolone injection. Ann Intern Med 157: 835-836.

Madrid H, Ruíz-Cendoya M, Cano J, Stchigel A, Orofino R, Guarro J. 2009. Genotyping and in vitro antifungal susceptibility of Neoscytalidium dimidiatum isolates from different origins. Int J Antimicrob Agents 34: 351-354.

Malani PN, Bleicher JJ, Kauffman CA, Davenport DS. 2001. Disseminated Dactylaria constricta infection in a renal transplant recipient. Transpl Infect Dis 3: 40-43.

Mathews MS, Maharajan SV. 1999. Exserohilum rostratum causing keratitis in India. Med Mycol 37: 131-132.

McGinnis MR, Pasarell L. 1998. In vitro evaluation of terbinafine and itraconazole against dematiaceous fungi. Med Mycol 36: 243-246.

McGinnis MR, Pasarell RL, Sutton DA. 1997. In vitro evaluation of voriconazole against some clinically important fungi. Antimicrob Agents Chemother 41: 1821-1834.

McGinnis MR, Lemon SM, Walker DH, de Hoog GS, Haase G. 1999. Fatal cerebritis caused by a new species of $\mathrm{Cla}$ dophialophora. Stud Mycol 43: 166-171.

Mendoza L, Karuppayil SM, Szaniszlo PJ. 1993. Calcium regulates in vitro dimorphism in chromoblastomycotic fungi. Mycoses 36: 157-164.

Mershon-Shier KL, Deville JG, Delair S, Fothergill AW, Wickes B, de Hoog GS, Sutton DA, Lewinski MA. 2011. Aureobasidium pullulans var. melanigenum fungemia in a pediatric patient. Med Mycol 49: 80-83.

Mise N, Ono Y, Kurita N, Sai K, Nishi T, Tagawa H, Sugimoto T. 2008. Aureobasidium pullulans peritonitis: Case report and review of the literature. Perit Dial Int 28: 679_ 681.

Moody MN, Tschen J, Mesko M. 2012. Cutaneous Curvularia infection of the forearm. Cutis 89: 65-68.

Morton SJ, Midthun K, Merz WG. 1986. Granulomatous encephalitis caused by Bipolaris hawaiiensis. Arch Pathol Lab Med 110: 1183-1185.

Mostert L, Groenewald JZ, Summerbell RC, Robert V, Sutton DA, Padhye AA, Crous PW. 2005. Species of Phaeoacremonium associated with infections in humans and environmental reservoirs in infected woody plants. $J$ Clin Microbiol 43: 1752-1767.

Mostert L, Groenewald JZ, Summerbell RC, Gams W, Crous PW. 2006. Taxonomy and pathology of Togninia and its Phaeocacremonium anamorphs. Stud Mycol 54: 1-115.

Najafzadeh MJ, Badali H, Illnait-Zaragozi MT, de Hoog GS, Meis JF. 2010a. In vitro activities of eight antifungal drugs against 55 clinical isolates of Fonsecaea spp. Antimicrob Agents Chemother 54: 1636-1638.

Najafzadeh MJ, Sun J, Vicente V, Xi L, Gerrits van den Ende AHG, de Hoog GS. 2010b. Fonsecaea nubica sp. nov., a new agent of human chromoblastomycosis revealed using molecular data. Med Mycol 48: 800-806.

Najafzadeh MJ, Suh MK, Lee MH, Ha GY, Kim JR, Kim TH Lee HJ, Choi JS, Meis JF, de Hoog GS. 2013. Subcutaneous phaeohyphomycosis caused by Exophiala
Black Molds and Yeasts Pathogenic to Humans

equina, with susceptibility to eight antifungal drugs. J Med Microbiol 62: 797-800.

Najafzadeh MJ, Sutton DA, Keisari MS, Zarrinfar H, de Hoog GS, Chowdhary A, Meis JF. 2014. In vitro activity of 8 antifungal drugs against 104 environmental and clinical isolates of Aureobasidium pullulans. Antimicrob Agents Chemother pii: AAC/03095-14.

Negroni R, Helou SH, Petri N, Robles Am, Arechavala A, Bianchi MH. 2004. Case study: Posaconazole treatment of disseminated phaeohyphomycosis due to Exophiala spinifera. Clin Infect Dis 38: e15-e20.

Negroni R, Tobon A, Bustamante B, Shikanai-Yasuda MA, Patino H, Restrepo A. 2005. Posaconazole treatment of refractory eumycetoma and chromoblastomycosis. Rev Inst Med Trop Sao Paulo 47: 339-346.

Newell CK, Steinmetz RL, Brooks HL Jr. 2006. Chronic postoperative endophthalmitis caused by Bipolaris australiensis. Retina 26: 109-110.

Ogden PE, Hurley DL, Cain PT. 1992. Fatal fungal endarteritis caused by Bipolaris spicifera following replacement of the aortic valve. Clin Infect Dis 14: 596-598.

Padhye AA, Davis MS, Baer D, Reddick A, Sinha KK, Ott J. 1998. Phaeohyphomycosis caused by Phaeoacremonium inflatipes. J Clin Microbiol 36: 2763-2765.

Padin C, Fernandez-Zeppenfeldt G, Yegres F, Richard-Yegres N. 2005. Scytalidium dimidiatum: Opportunistic fungus for humans and Mangifera indica in Venezuela. Revta Iberoam Micol 22: 172-173.

Panda A, Das H, Deb M, Khanal B, Kumar S. 2006. Aureobasidium pullulans keratitis. Clin Experiment Ophthalmol 34: $260-264$.

Pauzner R, Goldschmied-Reouven A, Hay I, Vered Z, Ziskind Z, Hassin N, Farfel Z. 1997. Phaeohyphomycosis following cardiac surgery: Case report and review of serious infection due to Bipolaris and Exserohilum species. Clin Infect Dis 25: 921-923.

Pedersen MB, Zhao Y, Arendrup MC, Bendix K, BojsenMøller M, Mølle I, D’Amore F. 2011. Co-existence of cerebral infection with Rhinocladiella mackenziei and primary central nervous system lymphoma in a HIV-negative patient. APMIS 119: 221-223.

Perfect JR, Marr KA, Walsh TJ, Greenberg RN, DuPont B, de la Torre-Cisneros J, Just-Nübling G, Schlamm HT, Lutsar I, Espinel-Ingroff A, et al. 2003. Voriconazole treatment for less common, emerging or refractory fungal infections. Clin Infect Dis 36: 112-1131.

Piepenbring M, Cáceres Mendez OA, Espino Espinoza AA Kirschner R, Schöfer H. 2007. Chromoblastomycosis caused by Chaetomium funicola: A case report from Western Panama. Br J Dermatol 157: 1025-1029.

Pikazis D, Xynos ID, Xila V, Velegraki A, Aroni K. 2009. Extended fungal skin infection due to Aureobasidium pullulans. Clin Exp Dermatol 34: e892-e894.

Queiroz-Telles F, Esterre P, Perez-Blanco M, Vital RG, Salgado CG, Bonifaz A. 2009. Chromoblastomycosis: An overview of clinical manifestations, diagnosis and treatment. Med Mycol 47: 3-15.

Revankar SG, Sutton DA. 2010. Melanized fungi in human disease. Clin Microbiol Rev 23: 884-928. 
A. Chowdhary et al.

Reyes FA, Buchman MT. 1986. Phialophora richardsiae infection mimicking a soft tissue mass of a finger. J Hand Surg 11: 274 .

Rishi K, Font RL. 2003. Keratitis caused by an unusual fungus, Phoma species. Cornea 22: 166-168.

Ritter JM, Muehlenbachs A, Blau DM, Paddock CD, Shieh WJ, Drew CP, Batten BC, Bartlett JH, Metcalfe MG, Pham $\mathrm{CD}$, et al. 2013. Exserohilum infections associated with contaminated steroid injections: A clinicopathologic review of 40 cases. Am J Pathol 183: 881-892.

Saenz RE, Brown WD, Sanders CV. 2001. Allergic bronchopulmonary disease caused by Bipolaris hawaiiensis presenting as a necrotizing pneumonia: Case report and review of literature. Am J Med Sci 321: 209-212.

Salkin IF, Martinez JA, Kemna ME. 1986. Opportunistic infection of the spleen caused by Aureobasidium pullulans. J Clin Microbiol: 23: 828-831.

Samerpitak K, Van der Linde E, Choi HJ, Gerrits van den Ende AHG, Machouart M, Gueidan C, de Hoog GS. 2014. Taxonomy of Ochroconis, genus including opportunistic pathogens on humans and animals. Fung Divers 65: 89-126.

Samerpitak K, Duarte APM, Attili-Angelis D, Pagnocca FC, Heinrichs G, Rijs AJMM, Alfjorden A, Gerrits van den Ende AHG, Menken SBJ, de Hoog GS. A new species of the oligotrophic genus Ochroconis (Sympoventuriaceae). Mycol Prog (in press).

Sang H, Zheng XE, Kong QT, Zhou WQ, He W, Lv GX, Shen YN, Liu WD. 2011. A rare complication of ear piercing: A case of subcutaneous phaeohyphomycosis caused by Veronaea botryosa in China. Med Mycol 49: 296-302.

Saunte DM, Tarazooie B, Arendrup MC, de Hoog GS. 2011. Melanized fungi in skin and nail: It probably matters. Mycoses 55: 161-167.

Seyedmousavi S, Badali H, Chlebicki A, Zhao JJ, PrenafetaBoldú FX, de Hoog GS. 2011. Exophiala sideris, a novel black yeast obtained by enrichment with toxic alkyl benzenes and arsenic. Fungal Biol 115: 1030-1037.

Sharkey PK, Graybill JR, Rinaldi MG, Stevens DA, Tucker RM, Peterie JD, Hoeprich PD, Greer DL, Frenkel L, Counts GW. 1990. Itraconazole treatment of phaeohyphomycosis. J Am Acad Dermatol 23: 577-586.

Sheyman AT, Cohen BZ, Friedman AH, Ackert JM. 2013. An outbreak of fungal endophthalmitis after intravitreal in jection of compounded combined bevacizumab and triamcinolone. JAMA Ophthalmol 131: 864-869.

Shin EJ, Guertler N, Kim E, Lalwani AK. 2003. Screening of middle ear effusion for the common sinus pathogen $\mathrm{Bi}$ polaris. Eur Arch Otorhinolaryngol 260: 78-80.

Sivanesan A. 1987. Graminicolous species of Bipolaris, Curvularia, Drechslera, Exserohilum, and their teleomorph (mycology papers), 261 pp. CABI, Wallingford, UK.

Smith RM, Tipple M, Chaudry MN, Schaefer MK, Park BJ. 2013. Relapse of fungal meningitis associated with contaminated methylprednisolone. N Engl J Med 368: 25352536.

Stiller MJ, Rosenthal S, Summerbell RC, Pollack J, Chan A. 1992. Onychomycosis of the toenails caused by Chaetomium globosum. J Am Acad Dermatol 26: 775776 .
Sudhadham M, Prakitsin S, Sivichai S, Chaiyarat R, Dorrestein GM, Menken SBJ, de Hoog GS. 2008. The neurotropic black yeast Exophiala dermatitidis has a possible origin in the tropical rain forest. Stud Mycol 61: 145155.

Tan DHS, Sigler L, Gibas CFC, Fong IW. 2008. Disseminated fungal infection in a renal transplant recipient involving Macrophomina phaseolina and Scytalidium dimidiatum: Case report and review of taxonomic changes among medically important members of the Botryosphaeriaceae. Med Mycol 46: 285-292.

Tanabe K, Seino M, Senda S. 2010. Superficial mycoses of the breast caused by Curvularia inaequalis. Eur J Dermatol 20: 658-659.

Thomas C, Mileusnic D, Carey RB, Kampert M, Anderson D. 1999. Fatal Chaetomium cerebritis in a bone marrow transplant patient. Hum Pathol 30: 874-879.

Togitani K, Kobayashi M, Sakai M, Uemura Y, Taguchi H, Morita T, Sugihara S, Sano A, Nishimura K. 2007. Ethmoidal sinusitis caused by Exserohilum rostratum in a patient with malignant lymphoma after non-myeloablative allogeneic peripheral blood stem cell transplantation. Transpl Infect Dis 9: 137-141.

Torstrick RF, Harrison K, Heckman JD, Johnson JE. 1979. Chronic bursitis caused by Phialophora richardsiae. J Bone Joint Surg Am 61: 772-774.

Toul P, Castillo L, Hofman V, Bouchara JP, Chanalet S, GariToussaint M. 2006. A pseudo tumoral sinusitis caused by Bipolaris sp. J Infect 53: e235-e237.

Tournas VH. 2005. Spoilage of vegetable crops by bacteria and fungi and related health hazards. Crit Rev Microbiol 31: $33-44$

Tullio V, Banche G, Allizond V, Roana J, Mandras N, Scalas D, Panzone M, Cervetti O, Valle S, Carlone N, et al. 2010. Non-dermatophyte moulds as skin and nail foot mycosis agents: Phoma herbarum, Chaetomium globosum and Microascus cinereus. Fungal Biol 114: 345-349.

Uezato H, Gushi M, Hagiwara K, Kayo S, Hosokawa A, Nonaka S. 2006. A case of tinea nigra palmaris in Okinawa, Japan. J Dermatol 33: 23-29.

Ungpakorn R. 2005. Mycoses in Thailand: Current concerns. Nippon Ishinkin Gakkai Zasshi 46: 81-86.

von Arx JA, Guarro J, Figueras MJ. 1986. The ascomycete genus Chaetomium. Beih Nova Hedwigia 84: 1-162.

Walz R, Bianchin M, Chaves ML, Cerski MR, Severo LC, Londero AT. 1997. Cerebral phaeohyphomycosis caused by Cladophialophora bantiana in a Brazilian drug abuser. J Med Vet Mycol 35: 427-431.

Wang X, Wang W, Lin Z, Wang X, Li T, Yu J, Liu W, Tong Z, Xu Y, Zhang J, et al. 2014. CARD9 mutations linked to subcutaneous phaeohyphomycosis and TH17 cell deficiencies. J Allergy Clin Immunol 11: 905-908.

Yeghen T, Fenelon L, Campbell CK, Warnock DW, Hoffbrand AV, Prentice HG, Kibbler CC. 1996. Chaetomium pneumonia in a patient with acute myeloid leukaemia. J Clin Pathol 49: 184-186.

Zaitz C, Heins-Vaccari EM, de Freitas RS, Arriagada GL, Ruiz L, Totoli SA, Marques AC, Rezze GG, Müller H, Valente NS, et al. 1997. Subcutaneous phaeohyphomycosis caused by Phoma cava. Report of a case and 
Black Molds and Yeasts Pathogenic to Humans

review of the literature. Rev Inst Med Trop Sao Paulo 39: 43-48.

Zalar P, de Hoog GS, Gunde-Cimerman N. 1999. Ecology of halotolerant dothideaceous black yeasts. Stud Mycol 43: 38-48.

Zeng JS, Sutton DA, Fothergill AW, Rinaldi MG, Harrak MJ, de Hoog GS. 2007. Spectrum of clinically relevant Exo- phiala species in the United States. J Clin Microbiol 45: 3713-3720.

Zhao Y, Petraitiene R, Walsh TJ, Perlin DS. 2013. A real-time PCR assay for rapid detection and quantification of Exserohilum rostratum, a causative pathogen of fungal meningitis associated with injection of contaminated methylprednisolone. J Clin Microbiol 51: 1034-1036. 


\section{$\& \mathrm{CSH} \&$ Cold Spring Harbor

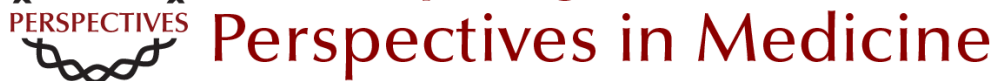

\section{Black Molds and Melanized Yeasts Pathogenic to Humans}

Anuradha Chowdhary, John Perfect and G. Sybren de Hoog

Cold Spring Harb Perspect Med 2015; doi: 10.1101/cshperspect.a019570 originally published online November 10, 2014

Subject Collection Human Fungal Pathogens

\section{Evolutionary Perspectives on Human Fungal Pathogens John W. Taylor}

Black Molds and Melanized Yeasts Pathogenic to Humans Anuradha Chowdhary, John Perfect and G. Sybren de Hoog

Fungal Pathogens: Survival and Replication within Macrophages

Andrew S. Gilbert, Robert T. Wheeler and Robin C. May

Innate Defense against Fungal Pathogens Rebecca A. Drummond, Sarah L. Gaffen, Amy G. Hise, et al.

Antifungal Pharmacokinetics and Pharmacodynamics Alexander J. Lepak and David R. Andes

Human Fungal Pathogens of Mucorales and Entomophthorales

Leonel Mendoza, Raquel Vilela, Kerstin Voelz, et al.

Functional Profiling of Human Fungal Pathogen Genomes

Alexi I. Goranov and Hiten D. Madhani

Aspergillus fumigatus and Related Species Janyce A. Sugui, Kyung J. Kwon-Chung, Praveen R. Juvvadi, et al.
Thermally Dimorphic Human Fungal Pathogens-Polyphyletic Pathogens with a Convergent

Pathogenicity Trait Anita Sil and Alex Andrianopoulos

Mechanisms of Antifungal Drug Resistance Leah E. Cowen, Dominique Sanglard, Susan J. Howard, et al.

Treatment Principles for Candida and Cryptococcus Laura C. Whitney and Tihana Bicanic

The Human Mycobiome Patrick C. Seed

Treatment Principles for the Management of Mold Infections

Dimitrios P. Kontoyiannis and Russell E. Lewis

Adaptive Immunity to Fungi Akash Verma, Marcel Wüthrich, George Deepe, et al.

The Candida Pathogenic Species Complex Siobhán A. Turner and Geraldine Butler

Fungal Morphogenesis Xiaorong Lin, J. Andrew Alspaugh, Haoping Liu, et al.

For additional articles in this collection, see http://perspectivesinmedicine.cshlp.org/cgi/collection/ 